\title{
CONSTRUCTION AND EVALUATION OF OPTIMAL PORTFOLIO USING SHARPE'S SINGLE INDEX MODEL - AN EMPIRICAL STUDY ON SELECTED STOCKS IN BANKING AND INFORMATION TECHNOLOGY SECTORS
}

\begin{tabular}{|c|c|c|}
\hline Mr.DharmanandaMontadka, & Dr. Anjali Ganesh, & Pavithra, \\
Assistant Professor, Department of Business & Professor, Department of Business & Year MBA, Alva's Institute of \\
Administration Alva's Institute of Engineering \& & Administration, St. Joseph & Engineering \& Technology, \\
Technology, Shobhavana Campus, Mijar, Moodbidri & Engineering College Vamanjoor, & Shobhavana Campus, Mijar, \\
& Mangalore.. & Moodbidri. \\
\hline
\end{tabular}

\begin{abstract}
Portfolio is the combinations of securities where in investors have to select best stocks among available stocks. Portfolio construction is an important process of the investors for investment in the equity market. The main purpose of this research is to construct an optimal portfolio in Indian stock market with the help of the Sharpe single index model. A good selection of portfolio gives maximum returns with moderate risk. In this paper, 50 selected stocks from the various Banking and Information Sectors have been taken into consideration and these selected stocks are constituent of the NSE Nifty index. The daily data for all the stocks for the period of $1^{\text {st }}$ January 2014 to $31^{\text {st }}$ December 2014 have been considered. By keeping these views in mind this paper tries to explore the ways to construct an optimal portfolio by using Sharpe index model. Sharpe index model proposes to combine high risk securities with low risk securities to even out the risk. The research tries to give suggestions to investors based on the findings that help them to build optimal portfolio.
\end{abstract}

Keywords: Optimal Portfolio, Risk and Return trade off, Beta, portfolio construction, Diversification.

\section{INTRODUCTION}

"Matching the market is an inefficient investment strategy - even in an informationally efficient market"

Robert A Haugen and Nardin L Barker (1991)

A portfolio is a combination of financial assets involving tools such as bonds, foreign exchange, gold, real estate certificates, shares, and bank deposits which are held concurrently by one person or a group of persons. Risk is the possibility of losses one incurred on portfolio investment and the return is the profit one gets from portfolio investment. Markowitz states that, the expected return and standard deviation of return of a portfolio are the standards for portfolio construction. These parameters can be used as a possible maxim for how investors need to act.The whole model is based on an economic element of "Expected Utility". The concept of utility is based on the fact that different investors have different investment objectives and can be satisfied in different ways. There are many investors who want to invest their savings in various investment products to gain a return and those who are risk takers they invest their savings in the stock market. Stock market is a volatile market which moves towards up and down on the basis of economic concept demand and supply. There are two types of Portfolio constructions; they are Traditional Approach and Modern Approach. The traditional approach is based on 
Current Income, Capital Appreciation, Tax Considerations, Liquidity and Security and safety of the portfolio.

The portfolio can comprise of Bonds and Common Stock or only Bonds or only Common Stocks. After selecting the type of portfolio the risk and return of the selected type is measured. Likewise, the Modern approach of portfolio construction comprises of three methods.

They are Markowitz Model of portfolio construction which was developed by Harry M. Markowitz in 1969, the Sharpe Index Model of portfolio construction developed by William Sharpe and later John Linter and Jan Mossin formulated the development of the Capital Asset Pricing Model of portfolio construction.

\section{OBJECTIVES}

- To present an assessment of past works relating to optimal portfolio construction and analysis.

- To build an optimal stock portfolio among selected stocks belonging to the Banking \& Information Technology in India, using Sharpe Single Index model.

- To calculate the amount of investment to be made into each of the stock that is included in theoptimal stock portfolio that is constructed using Sharpe index model.

\section{METHODOLOGY}

Research methodology is a practice to solve the research problem systematically. It involves collecting data, use of statistical techniques, analysis, and drawing conclusions about the research data. It is a blueprint, which is followed to complete the study.

The relevant data has been collected from the secondary sources of information (www.Bseindia.com).Thesecondary data has been extracted from the websites like Bombay Stock Exchange (BSE), Reserve Bank of India (RBI), books and journals.

\section{SAMPLE SIZE:}

Sample is a part of target population, which is carefully selected to represent the population. The sample size of the companies is 50 companies relating to banking and information technology.

\section{LITERATURE REVIEW:}

KapilSenand CA DishaFattawat(2014)in their study "Sharpe's Single Index Model and its Application Portfolio Construction: An Empirical Study" found that the construction of optimal portfolio investment by using Sharpe's Single Index Model is easier and more comfortable than by using Markowitz's Mean-Variance Model. Dr.K.V.Ramanathan and K.N. Jahnavi(2014) in their study, "Construction of optimal equity portfolio using the Sharpe's index model with reference to Banking and Information technology sectors in India from 2009-2013" found that the share market is more challenging, fulfilling and 
rewarding to investors willing to learn the trade for having effective returns with minimum risk involved.

Dr.B.Ravichandra Reddy and Ms DippiVerma(2013) in their study," Construction of Portfolio using Sharpe's Index model with Special Reference to Construction Industry in India" they conclude that the construction sector shows low risk in terms of Beta. Investors should not only look on the BETA when making decisions in construction companies. In the
Indian scenario, Vardharajan (2011) constructed an optimal equity portfolio with the help of Sharpe index model. The study was conducted with the financial data from April 2006 to March 2011. The sample size was limited to 19 . He took companies from Banking and Information Technology. The portfolio was constructed with the top 5 stocks that meet the criteria to be included in the portfolio according to Sharpe Index model.

Analysis and Findings :

\section{$C_{i}$ calculations for stocks in the year 2014}

\begin{tabular}{|c|c|c|c|c|c|c|}
\hline $\begin{array}{l}\text { Sl. } \\
\text { No }\end{array}$ & Stocks & $\frac{\left(\boldsymbol{R}_{i}-\boldsymbol{R}_{\boldsymbol{f}}\right) \boldsymbol{\beta}_{i}}{\boldsymbol{\sigma}_{e i}^{2}}$ & $\sigma_{m}^{2} \sum_{I=1}^{N} \frac{\left(R_{i}-R_{f}\right) \beta_{i}}{\sigma_{e i}^{2}}$ & $\frac{\beta_{i}^{2}}{\sigma_{e i}^{2}}$ & $\begin{array}{l}1 \\
+\sigma_{m}^{2} \sum_{i=1}^{N} \frac{\beta_{i}^{2}}{\sigma_{e i}^{2}}\end{array}$ & $\mathbf{C}_{\mathbf{I}}$ \\
\hline 1 & $\begin{array}{l}\text { Software } \\
\text { technologies }\end{array}$ & 0.000459 & 0.009774 & 3.65E- & 1.009061 & 0.0096 \\
\hline 2 & $\begin{array}{l}\text { Dion global } \\
\text { solutions }\end{array}$ & 0.003677 & 0.005548 & 0.0011 & 1.003693 & 0.0055 \\
\hline 3 & Cyient & 0.002462 & 0.007103 & 0.0022 & 1.005135 & 0.0070 \\
\hline 4 & $\begin{array}{l}\text { Kellton tech } \\
\text { solutions }\end{array}$ & 0.019948 & 0.019823 & 0.0269 & 1.022268 & 0.0193 \\
\hline 5 & Sonata & 0.113168 & 0.091183 & 0.1572 & 1.121483 & 0.0813 \\
\hline 6 & $\begin{array}{l}\text { City union } \\
\text { Bank }\end{array}$ & 0.028578 & 0.109234 & 0.0843 & 1.174758 & 0.0929 \\
\hline 7 & Zensar & 0.021906 & 0.123071 & 0.0729 & 1.220859 & 0.1008 \\
\hline 8 & Aftek ltd & 0.017123 & 0.133886 & 0.0606 & 1.259154 & 0.1063 \\
\hline 9 & $\begin{array}{l}\text { State bank of } \\
\text { Bikaner and } \\
\text { Jaipur }\end{array}$ & 0.050289 & 0.165651 & 0.2072 & 1.390031 & 0.1191 \\
\hline 10 & HCL & 0.012794 & 0.173732 & 0.0551 & 1.42486 & 0.1219 \\
\hline 11 & Tata elxsi & 0.045386 & 0.202399 & 0.2046 & 1.55414 & 0.1302 \\
\hline
\end{tabular}


Asia Pacific Journals

\begin{tabular}{|c|c|c|c|c|c|c|}
\hline 12 & Indusind bank & 0.052266 & 0.235412 & 0.2415 & 1.706729 & 0.1379 \\
\hline 13 & $\begin{array}{l}\text { KotakMahindr } \\
\text { a }\end{array}$ & 0.097536 & 0.297019 & 0.4514 & 1.991888 & 0.1491 \\
\hline 14 & $\begin{array}{l}\text { AcceleyaKale } \\
\text { Solutions }\end{array}$ & 0.01103 & 0.303986 & 0.0576 & 2.028328 & 0.1498 \\
\hline 15 & $\begin{array}{l}\text { ING vysya } \\
\text { bank }\end{array}$ & 0.00852 & 0.309368 & 0.0469 & 2.057979 & 0.1503 \\
\hline 16 & $\begin{array}{l}\text { HexawareTech } \\
\text { nologies }\end{array}$ & 0.015164 & 0.318946 & 0.0897 & 2.114655 & 0.1508 \\
\hline 17 & NIIT & 0.126004 & 0.398534 & 0.7948 & 2.616718 & 0.1523 \\
\hline 18 & Federal bank & 0.025432 & 0.414598 & 0.1849 & 2.733514 & 0.1516 \\
\hline 19 & $\begin{array}{l}\text { Tata } \\
\text { consultancy }\end{array}$ & 0.010036 & 0.420938 & 0.0730 & 2.779653 & 0.1514 \\
\hline 20 & AGC ltd & 0.023578 & 0.43583 & 0.1728 & 2.888809 & 0.1508 \\
\hline 21 & HDFC & 0.013126 & 0.444121 & 0.1017 & 2.953077 & 0.1503 \\
\hline 22 & $\begin{array}{l}\text { Bank of } \\
\text { Baroda }\end{array}$ & 0.077548 & 0.493104 & 0.6107 & 3.338822 & 0.1476 \\
\hline 23 & Geomatric & 0.027296 & 0.510345 & 0.2337 & 3.486477 & 0.1463 \\
\hline 24 & $\begin{array}{l}\text { KPIT } \\
\text { Technologies }\end{array}$ & 0.006364 & 0.514365 & 0.0561 & 3.521923 & 0.1460 \\
\hline 25 & $\begin{array}{l}\text { South indian } \\
\text { Bank }\end{array}$ & 0.008636 & 0.51982 & 0.0767 & 3.570426 & 0.1455 \\
\hline 26 & $\begin{array}{l}\text { CMC } \\
\text { Technologies }\end{array}$ & 0.006237 & 0.523759 & 0.0558 & 3.605698 & 0.1452 \\
\hline 27 & $\begin{array}{l}\text { Financial } \\
\text { Technologies }\end{array}$ & 0.026676 & 0.540609 & 0.2513 & 3.764488 & 0.1436 \\
\hline 28 & Canara Bank & 0.066667 & 0.582718 & 0.6874 & 4.198717 & 0.1387 \\
\hline 29 & $\begin{array}{l}\text { Corporation } \\
\text { Bank }\end{array}$ & 0.012205 & 0.590427 & 0.1296 & 4.28058 & 0.1379 \\
\hline 30 & $\begin{array}{l}\text { Oriental Bank } \\
\text { of Commerce }\end{array}$ & 0.057647 & 0.626839 & 0.6645 & 4.700301 & 0.133 \\
\hline 31 & $\begin{array}{l}\text { Allahabad } \\
\text { Bank }\end{array}$ & 0.414166 & 0.88844 & 5.5756 & 8.222056 & 0.1080 \\
\hline
\end{tabular}


Asia Pacific Journals

\begin{tabular}{|c|c|c|c|c|c|c|}
\hline 32 & $\begin{array}{l}\text { Syndicate } \\
\text { Bank }\end{array}$ & 0.111234 & 0.9587 & 1.5037 & 9.171876 & 0.1045 \\
\hline 33 & Vijaya Bank & 0.014213 & 0.967677 & 0.1921 & 9.293248 & 0.1041 \\
\hline 34 & $\begin{array}{l}\text { Karnataka } \\
\text { Bank }\end{array}$ & 0.031358 & 0.987483 & 0.4972 & 9.607331 & 0.1027 \\
\hline 35 & $\begin{array}{l}\text { Bank of } \\
\text { Maharashtra }\end{array}$ & 0.02423 & 1.002787 & 0.4450 & 9.888411 & 0.1014 \\
\hline 36 & Bank of India & 0.038626 & 1.027185 & 0.7758 & 10.37845 & 0.0989 \\
\hline 37 & IDBI & 0.026712 & 1.044057 & 1.0123 & 11.01786 & 0.0947 \\
\hline 38 & UCO Bank & -1.18585 & 0.295031 & -68.21 & -32.0721 & -0.0099 \\
\hline 39 & $\begin{array}{l}\text { Dhanalaxmi } \\
\text { Bank }\end{array}$ & 0.021513 & 0.308619 & 2.7546 & -30.3322 & -0.0101 \\
\hline 40 & Dena Bank & $-8.8 \mathrm{E}-05$ & 0.308564 & 0.0685 & -30.2889 & -0.0101 \\
\hline 41 & Oracle & $-2.3 \mathrm{E}-05$ & 0.30855 & 0.0050 & -30.2857 & -0.0101 \\
\hline 42 & Wipro & -0.00018 & 0.308436 & 0.0060 & -30.2819 & -0.0101 \\
\hline 43 & Axis bank & -0.07581 & 0.260554 & 2.0533 & -28.9849 & -0.0089 \\
\hline 44 & SBI & -0.00781 & 0.255624 & 0.0796 & -28.9346 & -0.0088 \\
\hline 45 & ICICI Bank & -0.0131 & 0.247347 & 0.1252 & -28.8555 & -0.0085 \\
\hline 46 & Mphasis & -0.00192 & 0.246132 & 0.0180 & -28.8441 & -0.0085 \\
\hline 47 & $\begin{array}{l}\text { Sterling } \\
\text { enterprises }\end{array}$ & -0.02519 & 0.230221 & 0.1630 & -28.741 & -0.0080 \\
\hline 48 & Infosys & -0.00299 & 0.228331 & 0.0111 & -28.734 & -0.0079 \\
\hline 49 & $\begin{array}{l}\text { Cat } \\
\text { Technologies }\end{array}$ & -0.03912 & 0.203622 & 0.1272 & -28.6536 & -0.0071 \\
\hline 50 & Empower India & -0.00061 & 0.203236 & 0.0009 & -28.653 & -0.0070 \\
\hline
\end{tabular}

Proportion of Investment in each stock in the year 2014:

\begin{tabular}{|c|l|c|}
\hline Sl. No. & \multicolumn{1}{|c|}{ Stocks } & Proportion of Investment \\
\hline 1 & Software technologies & -5.49789 \\
\hline 2 & Dion global solutions & 8.98068 \\
\hline 3 & Cyient & 4.093619 \\
\hline 4 & Kellton tech solutions & 4.902388 \\
\hline
\end{tabular}


Asia Pacific Journals

\begin{tabular}{|c|l|c|}
\hline 5 & Sonata & 42.16274 \\
\hline 6 & City union bank & 7.008051 \\
\hline 7 & Zensar & 4.980302 \\
\hline 8 & Aftek ltd & 2.404558 \\
\hline 9 & State bank of Bikaner and Jaipur & 4.966544 \\
\hline 10 & HCL & 3.584634 \\
\hline 11 & Tata elxsi & 6.235879 \\
\hline 12 & Indusind bank & 4.179904 \\
\hline 13 & Kotak Mahindra & 8.935414 \\
\hline 14 & Acceleya Kale Solutions Ltd & 1.131224 \\
\hline 15 & ING vysya bank & 0.572927 \\
\hline 16 & Hexaware Technologies & 0.438228 \\
\hline 17 & NIIT Technologies & 0.920701 \\
\hline
\end{tabular}

\section{Proportion of Investment in the year 2014}

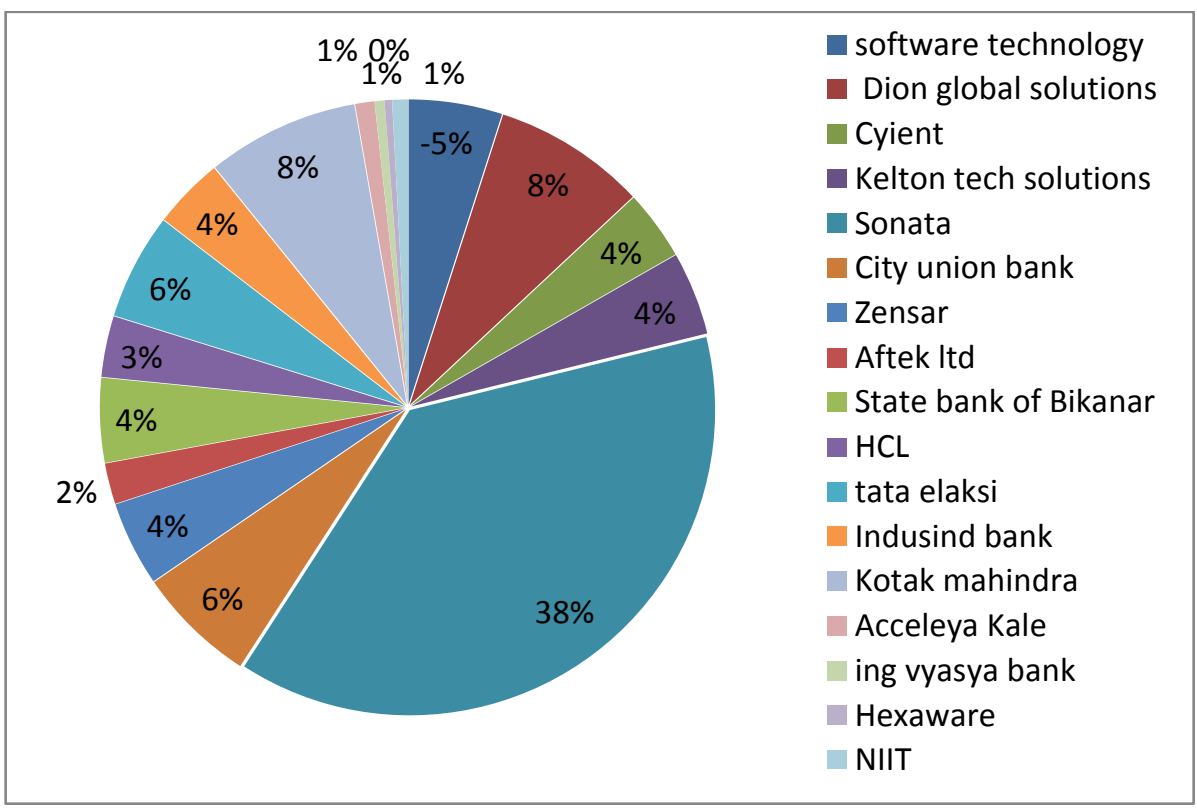

- It is observed that among the stocks under study, Kellton tech solutions ranked first in terms of annual returns with $0.779611 \%$ return and Cat Technologies obtained the least rank, i.e., $50^{\text {th }}$ rank, with $-0.32244 \%$ return. In terms of systematic risk,
Software technology has the lowest risk and Bank of India has the highest risk compared to other stocks under study. UCO Bank has the lowest unsystematic risk and Kellton tech solutions have the highest unsystematic risk compared to 
other stocks under study. Dhanalaxmi Bank has the lowest total risk and Kellton tech solutions has the highest total risk compared to other stocks under study.

- It is clear that Software technologies stock has the highest (12.58215) excess returnbeta ratio and Empower India has the lowest (-0.62348) excess return-beta ratio. The excess return to beta ratio was calculated using $9 \%$ as risk free rate of return which is the bank rate of the year 2014. It is also shown in the table that the cut-off point is 0.1523031 and it is obtained for the seventeenth stock, which is ranked in terms of excess return to beta ratio. As per the rule, the stocks above $\mathrm{C}^{*}$ can be included in the portfolio.

- It is clear from the table that highest proportion of investment is to be made (i.e., (i.e. $42.162 \%$ ) in Sonata stock and lowest investment is to be made ((i.e., $5.49789 \%)$ ) in Software technologies stock.

- It shows the proportion of investment to be made in each stock. It is clear from the table that highest proportion of investment is to be made (i.e., (i.e. $42.162 \%$ ) in Sonata stock and lowest investment is to be made ((i.e., $5.49789 \%)$ ) in Software technologies stock.It is found in the study that among the stocks under study, Kellton tech solutions has highest annual return and
Cat Technologies has the lowest annual return. Therefore the comparatively the most profitable stock is Kellton tech solutions.

- It is clear from the study that Software technologies stock has the lowest systematic risk and Bank of India stock has the highest systematic risk compared to other stocks under study.

- It is revealed in the study that UCO Bank has the lowest unsystematic risk and Kellton tech solutions has the highest unsystematic risk compared to other stocks under study.

- In terms of total risk, it is found in the study that Dhanalaxmi Bank has the lowest total risk and Kellton tech solutions has the highest total risk compared to other stocks under study.

- As per study it is crystal clear that Software technologies stock has the highest (12.58215) excess return-beta ratio and Empower India has the lowest (0.62348 ) excess return-beta ratio.

- It is found in the study that the cut-off point is 0.1523031 and it is obtained for the seventeenth ranked stock.

- The study shows the fact that highest proportion of investment is to be made (i.e42.16274\%) in Sonata stock and lowest investment is to be made (i.e., $5.49789 \%$ ) in Software technologies stock to construct the optimal portfolio. 


\section{CONCLUSION}

Risk and Return are playing one important role in making any investment decision. Whenever investors making any investment factor, they consider risk and return. Where there is a high risk, there is a high return on investment. This study aims at studying the opportunities that are available for investors as per the risk and return is concerned. The existence of a cut-off rate is also extremely useful because most new securities that have an excess return-to beta ratio above the cut-off rate can be included in the optimal portfolio.Sharpe's model is a scientific technique which can be used to construct the optimal portfolio. The investor has to decide about the proportion of investment in each security as found in the study so as to make the investment more scientific. Among 50 companies based Sharpe's model 17 companies were selected for investment and highest proportion of investment is made to Sonata Company.

\section{References}

1. Dr.KW Ramanathan, K. N Jahnavi. (vol.2 issue 3 2014). "Construction of Optimal quity portfolio using Sharpe index model with reference to Banking and Information Technology."International Journal of Business and Administration research review , 122-131.

2. Varadharajan, P. (n.d.). Construction of Optimal Equity Portfolio Using Sharpe Index Model with Special Reference to Banking, Steel, Media \& Entertainment
Sectors In India. SPC ERA International Journal of E-Commerce and E-Banking Vol-1, No-1.

3. Kapil Sen and CA Disha FattawatISSN 0975-6477 Volume 6, Number 6 (2014), pp. 511-516 Sharpe's Single Index Model and its Application portfolio construction:An emperical study. (n.d.).

Global Journal of Finance and Management.ISSN 0975-6477 Volume 6, Number 6 (2014), pp. 511-516.

4. Andrea LD, W. L. (2003). Benifits from Asia pacific mutual fund investments with currency hedging. Review of quantitative finance and accounting, 21(1): 49-59. 